\title{
REAKTUALISASI FIQH INDONESIA (Telaah atas Kontribusi Pemikiran Hukum Hasbi ash- Shiddieqy)
}

\author{
Maimun Nawawi \\ (Dosen Tetap pada Jurusan Tarbiyah STAIN Pamekasan dan alumni Program S2 \\ konsentrasi Syari'ah IAIN Sunan Ampel Surabaya)
}

\begin{abstract}
Abstraks:
Figh Indonesia adalah hasil rumusan hukum Islâm para ahli hukum (mujtahid) Indonesia yang dijabarkan dari sumber hukum primernya (al-Qur'ân dan Hadîts) dengan mempertimbangkan situasi dan kondisi serta adat istiadat budaya bangsa ini, hal tersebut sudah lama bergulir, dan tidak sedikit hasil karya para mujtahid tentang figh yang sebenarnya sudah dapat dinikmati oleh bangsa kita. Salah seorang mujtahid yang memberikan kontribusi figh ala Indonesia adalah Hasbi ash-Shiddieqy. Tulisan ini akan mengkaji ulang pemikiran Hasbi tersebut dan menawarkan wacana figh baru yaitu figh yang berbasis lokalitas. Figh ini merupakan salah satu upaya reaktualisasi figh Indonesia.
\end{abstract}

\section{Kata Kunci:}

Fiqh Indonesia, reaktualisasi, madzhab, dan taqlîd

\section{Pendahuluan}

Figh atau yang sering dikenal dengan hukum Islâm merupakan hasil olah pikir kaum mujtahid terhadap sumber primer syarîlah Islâm pada masa para mujtahid madzhab. Dalam perkembangan selanjutnya, sejarah umat Islâm mencatat bahwa fiqh berhasil mengatur dan mengarahkan perbuatan spiritual manusia serta hubungan sosial mereka, di mana awal keberadaannya sudah terjadi pada masa kerasulan Muhammad SAW, yaitu dengan cara alQur'ân dijabarkan kembali ke dalam bentuk tuntunan dan pedoman yang lebih praktis sehingga dapat menjadi penggerak dan pengenal bagi perubahan masyarakatnya menuju kesejahteraan lahir dan bathin. 
Sejarah juga menceritakan bahwa figh sebagai hasil dari produk berfikir dan memahami apa yang tersirat di dalam al-Qur'ân telah berhasil merubah masyarakat jâhiliyah menjadi masyarakat yang Islâmî, penuh pengetahuan dan kedamaian antar sesama. Dengan demikian, tidak dapat dipungkiri lagi kalau figh telah mengatur perbuatan umat Islâm sejak lama, baik dalam lingkup intern umat Islâm maupun lingkup ekstern, yakni hubungannya dengan non Muslim.

Dalam perjalanan selanjutnya, figh berkembang pesat di daerah-daerah hingga ke pelosok daerah yang dibawa oleh para ulamâ' terkemuka di daerah masing-masing, sehingga sekitar tahun keempat hijriyah muncul berbagai aliran (madzhab) dalam figh. Munculnya berbagai madzhab tersebut di samping karena persoalan politik, juga karena adanya kultus indinvidual kepada salah seorang mujtahid ternama serta membudayanya sikap taqlîd. Maka tidak mengherankan jika timbul gerakan membela faham hukum mujtahid yang menjadi pujaannya dengan cara menampilkan argumentasi pendukung dan mencari kelemahan faham lawannnya, yang berujung kepada berkembang fanatisme ( $\left.t a^{\prime} a s h u b\right)$ madzhab.

Fanatisme mahzhab itulah yang nyaris menutup pintu ijtihâd, bahwa tidak ada lagi persoalan yang masih memerlukan proses ijitihadi, karena mereka anggap semua permasalahan yang ada sangkut pautnya dengan hukum figh sudah ter-cover dalam salah satu madzhab yang sudah ada, dan telah dibukukan dalam fatwa-fatwa fuqaha tentang hukum-hukum ijithadiyah maupun hukum-hukum iftradhiyah (prediktif). Namun demikian, jika dicermati berbagai tantangan perkembangan sosial budaya manusia, kemajuan di berbagai sektor, khususnya teknologi dan pengetahuan serta globalitas hubungan antar bangsa, menuntut adanya metode dan sistem istinbâth yang berbeda pula, tanpa menafikan sifatnya yang relevan di setiap tempat dan waktu (yasluh li kulli zamân wa makân).

Itulah yang kemudian memunculkan gerakan membuka kembali pintu ijtihâd selebar-lebarnya. Di berbagai negeri Islâm seperti Mesir, Pakistan, Sudan, Malaysia dan tidak ketinggalan di Indonesia, muncul gerakan ijtihâd dan reformasi (tajdîd) hukum Islâm untuk mencari jawaban solutif terhadap fenomena yang sedang terjadi di masyarakat dan membutuhkan kepastian hukum. Di Indonesia misalnya, sejak pra-kemerdekaan sudah banyak 
bermunculan para ahli figh yang telah berperan memberikan kontribusi pemikiran dalam bidang figh, salah satunya adalah Muhammad Hasbi ash-Shiddieqy, penggagas pertama figh indonesia yang rumusan fiqhnya telah memperkaya khazanah pemikiran hukum di Indonesia. Sekalipun hasil ijtihâdnya tidak begitu berkembang di negeri ini, namun patut dihargai sebagai sebuah karya agung sumbangan anak negeri yang dapat dikatakan masih langka, sehingga perlu diaktualisasikan kembali dan dianalisis agar dapat terungkap, mengapa hasil rumusannya kurang begitu membumi di hati para penduduk negeri ini.

Namun demikian, tulisan ini tidak berpretensi merombak tatanan yang sudah mapan yang diyakini oleh mayoritas kaum Muslim Indonesia, di mana dalam sifat dan tindakan 'ubudiyah dan mu'âmalah lebih memilih madzhab empat (madzâhib al-arba'ah) khususnya madzhab Syâfi'î yang terkenal lebih berhati-hati dan moderat dalam merumuskan hukum Islâm. Tetapi, tulisan ini sebagai upaya penyegaran dan dinamisasi pemikiran hukum yang selama ini mulai kelihatan lesu, stagnan, dan lebih memilih untuk mengikuti apa yang telah ada (taqlîd), sekali pun harus dipaksakan.

\section{Selayang Pandang Sosok Hasbi ash-Shiddieqy}

Muhammad Hasbi ash-Shiddieqy adalah seorang ulama Indonesia yang concern dalam bidang figh. Kata "ash-Shiddiqi" dinishbahkan kepada nama "Abû Bakar al-Shiddîq", karena ia memang memiliki hubungan nasab dengan shahabat Nabî yang paling utama tersebut melalui ayahnya, yakni Teuku Kadi Sri Maharaja Mangkubumi Husein bin Mas'ud. Sedangkan ibunya bernama Teuku Amrah binti Teuku Sri Maharaja Mangkubumi Abd Aziz. Hasbi lahir di Lhokseumawe pada 10 Maret $1904 .{ }^{1}$

Hasbi adalah seorang ulama dan cendekiawan Muslim yang ahli dalam berbagai bidang ilmu agama, seperti Ilmu Fiqh, Hadîts, Tafsîr dan ilmu Kalâm. Ia juga seorang penulis yang produkif dan seorang mujaddid (pembaru) terkemuka yang menyeru umat agar kembali kepada al-Qur'ân dan al-Sunnah. Jenjang pendidikannya dimulai dari Pesantren pimpinan ayahnya sendiri hingga berumur 12

\footnotetext{
1 Dewan Redaksi Ensiklopedi Islam, Ensiklopedi Islam (Jakarta: PT Ichtiar Baru van Hoeve, 2003), hlm. 94
} 
Tahun. Kemudian ia belajar di beberapa pesantren di Aceh sebelum akhirnya ia bertemu dengan seorang ulamâ' Muhammad bin Salim alKalali. Kepada ulamâ' inilah, Hasbi membekali dirinya dengan berbagai disiplin ilmu, seperti Nahwu, Sharaf, Mantiq, Tafsîr, Hadîts, dan lain sebagainya. Hasbi juga pernah belajar di Surabaya kepada Ustadz Umar Hubeisy, pimpinan Pondok Pesantren al-Irsyad.

Dengan bekal ilmu yang diperolehnya di beberapa tempat tersebut, Hasbi mulai terjun ke dunia pendidikan dan menjadi seorang pendidik dan mengajar di beberapa tempat, serta giat melakukan dakwah di Aceh dalam rangka mengembangkan paham pembaruan (tajdîd), untuk memberantas syirik, bid'ah, dan khurafat.

Karir Hasbi sebetulnya diawali dari bidang politik, namun tidak diteruskan, ia lebih condong ke lapangan pendidikan dan ilmu agama, khususnya di perguruan tinggi. Ia pernah menjabat sebagai Dekan Fakultas Syari'ah IAIN Sunan Kalijaga Yogyakarta (1960 1972). Pada Tahun itu pula ia diangkat sebagai Guru Besar dalam bidang Ilmu Syari'ah. Di samping itu, ia memegang jabatan penting lainnya di perguruan tinggi lain, seperti di Universitas Sultan Agung Semarang dan UII Yogyakarta. Yang terpenting dari sosok Hasbi adalah ia begitu tekun dalam menulis sehingga mendapat penghargaan sebagai salah seorang dari sepuluh penulis Muslim terkemuka di Indonesia tahun 1957/1958. ${ }^{2}$

Dalam bidang figh ia begitu banyak menulis, di antaranya adalah Pengantar Hukum Islam, Pengantar Ilmu Figh, Hukum-hukum fikih Islam, Dinamika dan Elastisitas Hukum Islam, dan lain sebagainya. Dalam bidang ini, Hasbi memiliki pendapat sendiri yang digali dari pendapat ulama figh terdahulu, dan pendapatnya yang paling populer adalah upaya menyusun figh Islâm yang berkepribadian Indonesia. Inilah yang menjadi fokus kajian pada tulisan ini.

\section{Fiqh Indonesia: Konstruksi Pemikiran Hasbi ala Indonesia}

Hasbi adalah pencetus pertama "figh Indonesia", di mana konsep itu dicetuskan pada saat ia berumur 36 tahun (sebelum kemerdekaan). Namun, waktu itu ide tersebut belum mendapat respon dari kalangan cendikiawan Muslim lainnya. Barangkali karena

\footnotetext{
2 Ibid., hlm. 95
} 
formulasi idenya yang masih lemah. ${ }^{3}$ Namun 20 tahun kemudian, tepatnya pada 1961, dalam sebuah orasi ilmiah yang berjudul "Syari'at Islam menjawab tantangan zaman" yang disampaikan pada acara Ulang Tahun IAIN Sunan Kalijaga Yogyakarta, Hasbi berseru: "Maksud mempelajari syari' at Islam di universitas-universitas Islam sekarang ini, supaya fiqh/syari'at Islam dapat menampung seluruh kemaslahatan masyarakat dan dapat menjadi pendiri utama bagi pembangunan hukum di tanah air kita tercinta ini, maksud saya supaya dapat menyusun suatu fiqh yang berkepribadian sendiri" ${ }^{4}$

Hasbi mendekati isu ini dengan mengajak para eksponen hukum Islâm untuk meningkatkan aktivitas ijtihâd dan mengkonstruksi figh ala Indonesia, figh yang diaplikasikan sejalan dengan karakter Indonesia. Menurutnya, yang berkembang di Indonesia selama ini tidak lain adalah fiqh Hijâzî yang dibangun atas dasar karakter masyarakat Hijaz, atau fiqh Misrî yang diciptakan atas dasar adat orang Mesir, atau bahkan figh Hindî yang dirumuskan berdasarkan atas adat istiadat masyarakat India. Sehingga tidak mengherankan jika karakteristik yang khusus dari masyarakat Indonesia telah dikesampingkan, karena figh asing tersebut telah dipaksakan penerapannya melalui taqlîd (meniru secara membabi buta). ${ }^{5}$ Demikian, Hasbi mempelopori pembangunan figh baru oleh kaum Muslim Indonesia yang berakar dari nilai-nilai khusus yang ada dalam masyarakat setempat dan sumber-sumber dasar syarî́ah serta logika hukum yang dikembangkan dalam semua madzhab hukum Islâm. ${ }^{6}$

Menurut Hasbi, ada tiga bentuk ijtihâd yang perlu digalakkan menuju figh Islâm yang berwawasan keindonesiaan, yaitu: (1) Ijtihâd dengan mengklasifikasikan hukum-hukum produk ulama madzhab masa lalu, tujuannya agar dapat dipilih pendapat yang masih cocok untuk diterapkan dalam masyarakat Indonesia; (2) Ijtihâd dengan

\footnotetext{
3Baca Ratno Lukita, "Pergumulan Hukum Islam dan Adat di Indonesia" dalam Pranata Islam di Indonesia, Pergulatan Sosial, Politik, Hukum dan Pendidikan, (Jakarta Logos Wacana Ilmu, 2002), hlm. 71.

"Hasbi ash-Shiddieqy, Shari'at Islam Menjawab Tantangan Zaman (Yogyakarta: IAIN, 1961), hlm. 46.

5 Ibid., hlm. 43.

6 Baca ash-Shiddieqy, Sejarah Pertumbuhan dan Perkembangan Hukum Islam (Jakarta: Bulan Bintang, 1971), hlm. 285.
} 
mengklasifikasikan hukum-hukum yang semata-mata didasarkan pada adat dan kebiasaan serta suasana masyarakat di mana hukum tersebut berkembang; (3) ijtihâd dengan mencari hukum-hukum terhadap masalah kontemporer yang timbul sebagai akibat dari kemajuan ilmu pengetahuan dan teknologi. ${ }^{7}$ Dengan demikian dapat diartikan bahwa ide "Figh Indonesia" yang dilontarkan Hasbi, di satu sisi, merupakan sebuah upaya mencoba menelurkan hukum Islâm yang sesuai dengan adat dan perubahan yang berkembang di Indonesia, dan, di sisi lain, sebagai upaya membebaskan budaya Indonesia dari budaya Arab dan menjadikan adat Indonesia sebagai salah satu sumber hukum di Indonesia. Keindonesiaan berorientasi konstitusional telah dimotori oleh para sarjana umum yang menguasai sistem hukum di Indonesia, tetapi kurang mereka mendalami prinsip-prinsip kembali kepada al-Qur'ân dan al-Sunnah.

\section{Metode Ijtihâd Hasbi ash-Shiddieqy}

Dalam menetapkan suatu hukum, Hasbi menggunakan beberapa metode yang antara lain dapat dilihat dari hasil ijtihâd-nya u terhadap suatu hukum, baik yang sudah ada nash-nya maupun yang belum sama sekali. Dalam menggali hukum bagi masalah-masalah baru, Hasbi menggunakan metode analogi deduksi rasional seperti yang dipakai Abû Hanîfah. Dalam hal ini, Hasbi, misalnya, pernah menolak fatwâ pengharaman jabat tangan dengan lain jenis yang bukan mahramnya. Bantahannya terhadap fatwâ Majlis Tarjih Muhammadiyah tersebut tertuang dalam sebuah artikel ${ }^{8}$ yang dimuat di harian Suara Umat Yogyakarta. Dalam artikel tersebutr, Hasbi menjelaskan alasan penolakannya, yaitu karena fatwâ tersebut didasarkan atas qiyâs. Menurutnya, mengharamkan sesuatu harus berdasarkan dalîl nash yang qath'î, tidak boleh dengan qiyâs. Tidak ada satu dalîl qath'î pun, baik dalam al-Qur'ân maupun Hadîts yang mengharamkan jabat tangan antara laki-laki dan perempuan. Tegasnya, pengharaman jabat tangan seperti dijelaskan di atas tidak didukung oleh dalîl qath' $\hat{\imath}$.

7Kamaruzzaman Bustamam-Ahmad, Islam Historis, Dinamika Studi Islam di Indonesia (Yogyakarta: Galang Press, 2002), hlm. 99.

8Ash-Shiddieqy, “Qiyas Tarjih yang Tidak Rajih”, Suara Umat (22 Juni 1956) 
Meng-qiyâs-kan jabat tangan dengan pandang memandang adalah tidak tepat, sebab di samping qiyâs hanya dapat digunakan dalam keadaan darurat. Di samping itu, menurut Hasbi, tafsîr larangan memandang tersebut pada awal ayat 30 surat al-Nûr (24)9 adalah larangan melihat bagian tubuh (aurat) perempuan atau lakilaki. Sedangkan muka, telapak tangan, dan telapak kaki perempuan serta bagian luar tubuh laki-laki bukanlah aurat. Keharaman melihat aurat itu dalam keadaan terbuka, jika tertutup tidaklah haram kecuali apabila melihatnya akan menimbulkan hal-hal yang tidak diinginkan.

Hasbi berpendapat, memecahkan masalah hukum hanya dengan menggunakan qiyâs, seperti konsepnya al-Syâfi'î, akan menimbulkan kesulitan dan kesempitan. Sebab qiyâs kadangkala tidak memenuhi tuntutan perubahan kebutuhan, sedangkan mashlahah terus menerus mengalami perubahan. ${ }^{10}$

Terhadap masalah-masalah yang sudah ditetapkan hukumnya oleh ulama masa lalu, baik ulamâ' Sunnî, dan semua madzhab yang ada bahkan Syî́ah, Khawîrij, dan lainnya, Hasbi menggunakan metode komparasi (muqârin), yakni membandingkan antara satu pendapat dengan pendapat yang lain dan memilih yang lebih dan lebih mendekati kebenaran dan didukung oleh dalil-dalil yang terkuat. ${ }^{11}$

\section{Shalat Jum'at: Sebuah Produk Pemikiran Hasbi.}

Sepanjang yang diketahui dalam catatan sejarah pemikiran Islâm di Indonesia sebelum tahun 1359 H/1940 M, bahkan sampai tahun $1381 \mathrm{H} / 1961 \mathrm{M}$, belum pernah terdengar suara yang menyampaikan gagasan seperti yang diajak oleh Hasbi. Oleh karena itu, sangatlah pantas kalau ia disebut sebagai orang yang kali pertama di kalangan pemikir Islâm di Indonesia yang mencetuskan gagasan seperti itu, bahkan sampai lama setelah konsep itu dicetuskan masih ada yang mempertanyakan dan bersikap bahwa

\footnotetext{
9 Terjemahan al-Qur'ân surat al-Nûr (24) ayat 30 adalah sebagai berikut: "Katakanlah kepada orang laki-laki yang beriman: "Hendaklah mereka menahan pandangannya dan memelihara kemaluannya; yang demikian itu adalah lebih suci bagi mereka. Sesungguhnya Allah Maha Mengetahui apa yang mereka perbuat". Lihat Departemen Agama RI., Al Quraan dan Terjemahnya (Jakarta: PT. Bumi Restu, 1979), hlm. 548.

10 Ash-Shiddieqy, Falsafah Hukum Islam (Jakarta: Bulan Bintang, 1975), hlm. 51.

11 Ibid., Pengantar Ilmu Fiqh (Jakarta: Bulan Bintang, 1974), hlm. 91.
} 
"tak perlu ada figh yang berdimensi ruang dan waktu; Figh Indonesia, Pakistan, atau yang lainya. 12

Salah satu hasil ijtihâd Hasbi yang bernuansa Figh Indonesia dapat dilihat pada masalah shalat Jum'at. Dalam pedoman shalat Jum'at, Hasbi mengatakan bahwa pada hari Jum'at tidak ada shalat dhuhur empat rakaat karena sudah diganti oleh shalat Jum'at dua rakaat. Karenanya, seseorang yang tidak sempat mengikuti shalat Jum'at, baik seluruh atau sebagian saja, atau orang yang berhalangan hadir berjamaah di masjid baik karena sakit atau karena sebab lain, atau kaum perempuan yang tidak wajib hadir shalat berjamaah di masjid harus bersembahyang Jum'at, baik secara bersama-sama maupun sendiri-sendiri. Jadi tidak boleh shalat dhuhur pada siang hari Jum'at, berjamaah. Lebih dari itu, khutbah bukanlah rukun atau syarat sahnya shalat Jum'at.

Pendapat Hasbi mengenai shalat Jum'at seperti dijelaskan di atas berbeda dengan pendapat jumhûr yang populer dianut di Indonesia. Karenanya, tidak mengherankan jika pendapat ghayru jumhûr menimbulkan pro-kontra di kalangan kaum Muslim di Indonesia. Salah satunya adalah polemik singkat antara Hamka yang membela pendapat jumhûr13 dengan Abd. Rahman B. yang mendukung pendapat Hasbi. Karena polemik antara keduanya, yang dimuat dalam Panji Masyarakat, menyinggung-nyinggung pendapatnya, maka Hasbi menjelaskan alasan pendapatnya dengan menulis artikel berjudul "Mengapa Saya Menyalahi Jumhur dan Mewajibkan Jum'at bagi yang Tidak ke Mesjid ?"14

Artikel tersebut Hasbi tersebut diawali dengan pernyataan, "tidak tersembunyi bagi umum, istimewa bagi yang membaca buku saya pedoman shalat, bahwa saya dalam beberapa masalah Jum'at menyalahi jumhur dan memilih madzhab ghayru jumhûr, yakni Ibn 'Abbas, dan Daud Ibn Ali Al-Qasimi, al-Hasan bin Shaleh yang kemudian dikuatkan oleh Ahmad Muhammad Syakir, seorang ulamâ' Hadîts abad ke-20."

\footnotetext{
12 Ali Yafi, “Mata Rantai yang Hilang”, Pesantren, Vol. II No. 2 (1985), hlm. 36

${ }^{13}$ Hamka,"Terima Kasih untuk al-Fadhil Abd. al-Rahman B.", Panji Masyarakat, Th. XVI No. 146 (1974).

14 Ash-Shiddieqy, "Mengapa Aku Menyalahi Jumhûr dan Mewajibkan Jum'at juga atas orang-orang yang tidak ke Mesjid", Al-Jami'ah, No. 7 Th. XIII (1974), hlm. 10.
} 
Untuk mempertahankan pendapatnya, Hasbi mengajukan lima butir argumentasi, yaitu:

1. Al-Qur'ân Surat al-Jumu'ah (62) ayat 9,15 di mana ayat tersebut menunjukkan bahwa shalat tengah hari pada hari Jum'at adalah shalat Jum'at. Perintah ayat ini ditujukan kepada semua orang tanpa terkecuali, baik laki-laki maupun perempuan, sehat ataupun sakit, berhalangan maupun tidak.

2. Hadîts 'Umar yang diriwayatkan Ahmad, al-Nasâ'̂̂, Ibn Majah, ibn Hibbân dan al-Bayhaqî, yakni, "shalat Safar dua rakaat, shalat hari raya kurban dua rakaat, shalat hari raya fitri dua rakaat, shalat Jum'at dua rakaat sempurna bukan dipendekkan. Demikian ketetapan Allâh melalui risâlah Muhammad saw."16

Hadîts tersebut jelas menyebutkan shalat Jum'at adalah dua rakaat yang utuh bukan karena dipendekkan. Karena itu, pendapat Sa'îd bin Zubayr yang mengatakan shalat Jum'at empat rakaat, yang dua rakaat diganti dengan khutbah, berlawanan dengan Hadîts Umar tersebut, dan pendapat ibn Zubayr menjadi gugur.

3. Hadîts yang diriwayatkan oleh al-Bukhârî dan Muslim dari Mâlik bin Huwayrits, "shalatlah kamu sebagaimana kamu melihat aku shalat". Seorang Muslim haruslah mencontoh Nabî dalam mengerjakan shalat, karena Nabî mengerjakan shalat Jum'at dua rakaat, maka umatnya seharusnya meniru apa yang telah dilakukan oleh Nabî di atas.

Praktik Nabî yang selalu mengerjakan shalat Jum'at secara bersama-sama (jama'atan) tidak dapat dijadikan dalil bahwa berjemaah adalah syarat sahnya shalat Jum'at. Sebab kalau kesimpulannya ditarik dengan cara demikian, maka seluruh shalat fardhu tidak akan sah, apabila tidak dikerjakan secara berjemaah. Bukankah Nabî selalu mengerjakan shalat fardhu (termasuk selain shalat Jum'at) dengan berjemaah?.

15 Terjemahan ayat tersebut adalah: "Hai orang-orang yang beriman, apabila diseru untuk bersembahyang pada hari Jum'at, maka pergilah untuk menyebut Allah dan tinggalkanlah dagangan. Itu lebih baik bagimu jika kamu mengetahuinya."Lihat Departemen Agama RI., Al Quraan, hlm. 933.

16 Al-Bayhaqî, Sunan al-Bayhaqî, Juz III (Beirut: Dâr al-Fikr, 1977), hlm. 199. 
4. Perintah Ibn Abbâs kepada juru adzan (muadzdzin) untuk mengganti seruan hayya 'alâ al-shalâh (marilah bersembahyang) menjadi shallû fî al-rihâl (sembahyanglah di tempatmu masingmasing) pada waktu hujan sedang turun. Perintah tersebut lebih memperjelas lagi bahwa berjama'ah bukanlah syarat sahnya shalat Jum'at. Alasan ibn Abbâs berbuat demikian adalah karena Nabî saw. juga berbuat demikian. Rasûl tidak pernah menyuruh para sahabat datang ke Masjid untuk berjamaah shalat Jum'at ketika sedang turun hujan. Orang yang tidak datang ke masjid karena turun hujan, ternyata tidak pergi ke tempat lain untuk berjema'ah.

5. Para ulama tidak sepakat dalam menetapkan jumlah jamấah bagi syarat sahnya shalat Jum'at berjemaah. Para ulamâ' bersengketa dalam menetapkan batas jumlah jamâ'ah yang harus hadir. Ibn Taymiyah berpendapat cukup tiga orang, ada yang mengatakan lima belas orang, ada juga yang mensyaratkan empat puluh orang, bahkan 80 orang. Hal ini disebabkan

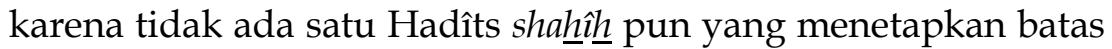
jumlah jamâ'ah shalat Jum'at, selain itu ada yang mengatakan sah dilakukan tanpa berjema'ah.

Dengan beberapa argumentasi seperti dijelaskan di atas, Hasbi berkesimpulan sama dengan pendapat ghayru jumhîr, bahwa shalat Jum'at adalah shalat asal pada hari Jum'at dan berjemaah bukanlah rukun shalat Jum'at.

Mengenai Khutbah termasuk rukun atau bukan, Hasbi mengatakan bahwa khutbah memang satu syi'ar Jum'at, akan tetapi para ulamâ' berbeda pendapat tentang hukum dan bilangannya, bahkan juga tentang duduk sejenak di antara dua khutbah. Jumhûr mengatakan bahwa hukum khutbah adalah fardhu, karenanya ia menjadi syarat sahnya shalat Jum'at. Akan tetapi Hasan al-Bishrî, Dawud bin Alî, al-Juwaynî dari Madzhab Syâfi'î, Abd al-Mâlik bin Habîb, dan Ibn Majsun berpendapat bahwa khutbah hanyalah sunnat saja, bukan fardhu. Sedangkan Ibn Hazm mengatakan bahwa khutbah adalah satu hal yang disyari'atkan, dan karenanya ia harus dikerjakan berdasarkan ittibấ.

Mengenai bilangan dan duduk sejenak di antara dua khutbah, al-Syâfi'î berpendapat bahwa khutbah harus dibacakan dalam dua babak. Karenanya, tidak sah khutbah yang dibacakan dalam satu 
babak tanpa berhenti sejenak. Walaupun para ulamấ berbeda pendapat tentang bilangan dan keharusan duduk sejenak, namun yang pasti menurut Hasbi, tidak ada Imâm empat yang berpendapat bahwa khutbah adalah rukun Jum'at.

Adapun dalil yang dipergunakan jumhîr bahwa lafadz $d z i k r$ Allâh yang tersebut dalam surat al-Jumu'ah ayat 9 adalah khutbah dan Nabî selalu berkhutbah, bahkan tetap sambil berdiri dalam rangkaian shalat Jum'at adalah lemah. Dalil fatwa thâbi'î Sâ'id ibn Zubayr seperti yang telah disebutkan di muka, menurut Hasbi, tidak dapat digunakan sebagai hujjah. Tidak ada seorang pun imam mujtahid yang mempergunakan fatwa thâbi'î sebagai hujjah, karena mereka tidak menderajatkan pendapat thâbi'î dengan pendapat shahabî. Pendapat thâbi'î bagi mereka hanya sekedar untuk menguatkan pendapat mereka saja, bukan untuk dijadikan sebagai dasar hujjah.

Hasbi mengatakan, bahwa al-Syawkanî telah membantah dalil-dalil yang telah dikemukakan oleh jumhûr. Menurutnya, yang dimaksud dzikr Allâh dalam Surat al-Jumu' ah ayat 9 adalah shalat itu sendiri, bukan khutbah. Jika maknanya mencakup khutbah tentu para mujtahid tidak berselisih pendapat tentang khutbah. Patut diingat bahwa orang yang menyampaikan khutbah selalu membelakangi kiblat, sedangkan shalat harus menghadap kiblat. Adapun tentang Nabî yang selalu mengerjakannya tidak menunjuk kepada yang wajib. Sesuatu yang baru menjadi wajib jika ada perintah khusus untuk mengerjakannya. Selain itu jika alasan wajib adalah karena selalu dikerjakan oleh Rasûlullâh, maka khutbah hari raya dan shalat sunnat fajar adalah wajib, karena Nabî selalu mengerjakannya. Karenanya, khutbah Jum'at hanyalah sunnah 'amaliyah, sama kedudukannya dengan shalat dua hari raya, shalat Fajar, dan sunnat witir.

Dengan argumentasi seperti tersebut di atas, Hasbi menarik kesimpulan yang sama dengan pendapat ghayru jumhûr bahwa khutbah tidak dapat dijadikan suatu fardhu yang berdiri sendiri, apalagi dijadikan rukun atau syarat syah shalat Jum'at. Mengerjakan shalat asal pada tengah hari Jum'at adalah shalat Jum'at, maka seseorang yang terlambat atau berhalangan hadir di Masjid untuk shalat Jum' at berjemaah dan kaum perempuan yang tidak diwajibkan 
datang ke masjid seharusnya pada tengah hari Jum'at mengerjakan shalat Jum'at bukan shalat dhuhur empat rakaat.

\section{Fiqh Berbasis Lokalitas: Konstruksi Baru Fiqh Indonesia}

Sebagaimana telah dijelaskan di awal bahwa Hasbi menggagas figh Indonesia yang mana pengambilan hujjahnya memperhatikan adat, kebiasaan, dan situasi yang sedang berkembang dalam masyarakat Indonesia secara nasional. Gagasan semacam itu sangatlah cocok dan relevan untuk masa-masa di mana pemikiran hukum Islâm belum marak berkembang -kalau tidak dapat dikatakan belum ada sama sekali-, terutama pada masa pra kemerdekaan.

Akan tetapi rumusan figh Indonesia yang dibidani Hasbi tersebut tidak begitu berkembang di negeri ini. Mengapa hal tersebut bisa terjadi? Menurut penulis, banyak faktor yang mencegah perkembangan aliran figh "baru" tersebut, yakni, antara lain: Pertama, kuatnya dukungan terhadap figh klasik yang sebelumnya telah dibukukan dan disosialisasikan oleh para pendukungnya, baik melalui pentaqridan terhadap kitab-kitab figh klasik maupun melalui penanaman keyakinan lewat organisasi-organisasi keagamaan, seperti Nahdlatul Ulamâ' (NU), yang secara tegas membatasi bolehnya bermadzhab hanya kepada empad madzhab (madzâhib al-arba'ah). Bahkan KH. Hasyim Asy'ary selaku pendiri Organisasi Nahdlatul Ulama (NU) secara tegas mengungkapkan bahwa menerima pendapat imam madzhab empat merupakan kemaslahatan yang besar (mashlahat al-adhîmah), dan sebaliknya menolaknya merupakan kerusakan dan kesalahan yang besar (mafsadah kabîrah). ${ }^{17}$

Kedua, kalau dianalisis lebih jauh pada masa sekarang, tampaknya untuk menciptakan suatu figh Indonesia yang didasarkan kepada adat dan kebiasaan masyarakat Indonesia, dan yang lebih mengarah pada penyatuan kesamaan pemikiran hukum Islâm dalam konteks keindonesiaan (national oriented), akan menemui banyak kesulitan. Hal tersebut dikarenakan, di satu sisi, Indonesia merupakan sebuah negara kepulauan yang penduduknya sangat beragam dari segi etnis dan budaya dengan adat dan kebisaan yang berbeda pula, sehingga untuk membentuk sebuah hukum yang

\footnotetext{
17 Baca Muhammad Hasyim Asy'ary, al-Tibyân fî al-nahy an muqatha'ati al-arhâm wa al-
} aqârib wa al-ikhwân (Jombang: Maktabah al-Turats al-Islâmî, 2004), hlm. 28. 
didasarkan kepada adat Indonesia akan menemui kesulitan, adat yang mana atau adat di daerah mana ? Di sisi yang lain, bukanlah sesuatu yang baru bahwa di Indonesia terdapat beberapa lembaga yang berkompeten dalam pesoalan hukum Islâm, misalnya MUI dan lembaga-lembaga lain di bawah naungan organisasi keagamaan. Namun, fatwa-fatwanya menjadi sekedar "formalitas" belaka yang tidak bisa membumi dalam masyarakat. Menurut hemat penulis, yang demikian itu disebabkan masyarakat Indonesia masih lebih mengedepankan "hukum adat" yang berlaku di daerahnya masingmasing, serta lebih mentaati ajaran (fatwâ) ulamâ' setempat.

Karenanya, untuk menyemarakkan kajian hukum Islâm dalam konteks keindonesiaan, penulis mendukung sebuah bentuk kajian Islâm yang sedang bergulir, yakni "figh berbasis kedaerahan/lokal", suatu bentuk pemikiran hukum Islâm yang muncul di setiap daerah di Indonesia yang sesuai dengan situasi dan kondisi daerah tersebut sejauh pemikiran tersebut membawa mashlahah. Misalnya nanti akan muncul hukum Islâm menurut madzhab Jatim, Jateng, dan Jabar serta propinsi-propinsi lain yang tidak menutup kemungkinan terdapat para ulama yang sebenarnya lebih concern dalam mencari solusi atas persoalan hukum yang menimpa masyarakat di daerahnya masing-masing.

Dalam konteks masyarakat madani, hukum Islâm "lokal" tidaklah bertentangan dengan syarî̀ah Islâm. Hukum Islâm yang berkembang dalam lintasan sejarah muslim sangat beragam, seperti hukum Islâm Hijaz, Kufah, Mesir, Syiria, dan India. Semua hukum Islâm yang berkembang tersebut merupakan hasil pemikiran ulamâ' setempat untuk menjawab persoalan yang muncul di daerah tersebut.18 Karena itu, hukum Islâm lebih bersifat lokal bukan nasional.

Adapun tata cara penggalian hukum Islâm atau penemuan figh lokal haruslah berasal dari hasil pemikiran ulamâ' setempat yang mengerti situasi, kondisi, dan adat isitadat masyarakatnya, serta mengerti seluk-beluk hukum Islâm ${ }^{19}$ di daerahnya. Jika muncul suatu

18Baca Marshall G. S. Hodgson, The Venture of Islam (Chicago dan London: The University of Chicago Press, 1977) hlm., 315-358. Lihat Juga Nouruzzaman Shiddiqi, Jeram-jeram Peradaban Muslim (Yokyakarta: Pustaka Pelajar, 1996), hlm. 22-27.

${ }_{19}$ Dalam hal ini, adat lebih merujuk pada tradisi dan peraturan lokal. 'Urf (adat) sendiri merupakan dasar hukum yang valid dalam figh, sebagaimana dinyatakan 
persoalan pada daerah tersebut, maka tidak perlu menunggu kongres, muktamar, dan lain sebagainya, tetapi cukup diselesaikan dan dijawab oleh ulamâ' setempat.

\section{Penutup}

Figh Indonesia merupakan konstruksi pemikiran Hasbi ala Indonesia. Munculnya pemikiran semacam ini, secara akademis, berawal dari kegelisahan Hasbi terhadap berbagai aplikasi figh yang berkarakter Hijaz dan Hindi, sehingga mengesampingkan sama sekali karakter keindonesiaannya. Karenanya, sebagai upaya mengkontruksi figh berkarakter keindonesiaan ini, Hasbi menggunakan metode analogi deduksi rasional dan metode komparatif. Dengan kedua metode tersebut, Hasbi memperkenalkan pemikirannya tentang shalat Jum'at sebagai bentuk kontribusinya dalam figh Indonesia. Namun demikian, beragamnya tradisi dan adat istiadat menyebabkan figh Indonesia sulit teraplikasikan. karenanya, perlu adanya konstruksi ulang figh Indonesia, yaitu figh Indonesia yang berbasis lokalitas, sebagai bentuk rekatualisasi figh Indonesia. Walhâh a'lam bi al-shawâb.

\section{Daftar Pustaka:}

Asy'ary, Muhammad Hasyim. al-Tibyân fî al-nahy an muqatha'ati alarhâm wa al-aqârib wa al-ikhwân. Jombang: Maktabah al-Turats alIslâmî, 2004.

Bayhaqî, Al-. Sunan al-Bayhaqî, Juz III. Beirut: Dâr al-Fikr, 1977.

Bustamam-Ahmad, Kamaruzzaman. Islam Historis, Dinamika Studi Islam di Indonesia. Yogyakarta: Galang Press, 2002.

Departemen Agama RI. Al Quraan dan Terjemahnya. Jakarta: PT. Bumi Restu, 1979.

dalam al-Qur'ân surat al-A'râf (7): 199 dan disebut dalam sebuah Hadîts yang diriwayatkan oleh Ibn 'Abbâs, yaitu, "sesuatu yang dipandang baik oleh umat maka di hadapan Allâh juga dipandang baik". Lihat John L. Esposito, et. al., The Oxford Encyclopaedia of the Modern Islamic Word (New York: Oxford University Press, 1995), hlm. 20 
Dewan Redaksi Ensiklopedi Islam. Ensiklopedi Islam. Jakarta: PT Ichtiar Baru van Hoeve, 2003.

Esposito, John L. et al. The Oxford Encyclopaedia of the Modern Islamic Word. New York: Oxford University Press, 1995.

Hamka,"Terima Kasih untuk al-Fadhil Abd. al-Rahman B.", Panji Masyarakat, Th. XVI No. 146 (1974).

Hodgson, Marshall G. S. The Venture of Islam. Chicago dan London: The University of Chicago Press, 1977.

Lukita,Ratno. "Pergumulan Hukum Islam dan Adat di Indonesia" dalam Pranata Islam di Indonesia, Pergulatan Sosial, Politik, Hukum dan Pendidikan. Jakarta Logos Wacana Ilmu, 2002.

Shiddieqy, Ash-. "Qiyas Tarjih yang Tidak Rajih", Suara Umat (22 Juni 1956)

------. Falsafah Hukum Islam. Jakarta: Bulan Bintang, 1975.

-----. Shari'at Islam Menjawab Tantangan Zaman. Yogyakarta: IAIN, 1961.

------. “Mengapa Aku Menyalahi Jumhûr dan Mewajibkan Jum'at Juga atas Orang-orang yang Tidak ke Mesjid", Al-Jami'ah, No. 7 Th. XIII (1974)

------. Sejarah Pertumbuhan dan Perkembangan Hukum Islam. Jakarta: Bulan Bintang, 1971.

------. Pengantar Ilmu Figh. Jakarta: Bulan Bintang, 1974.

Shiddiqi, Nouruzzaman. Jeram-jeram Peradaban Muslim. Yogyakarta: Pustaka Pelajar, 1996.

Yafi, Ali. “Mata Rantai yang Hilang”, Pesantren, Vol. II, No. 2 (1985). 